\title{
Does consideration of water routing affect simulated water and carbon dynamics in terrestrial ecosystems?
}

\author{
G. Tang ${ }^{1}$, T. Hwang ${ }^{2}$, and S. M. Pradhanang ${ }^{3}$ \\ ${ }^{1}$ Division of Earth and Ecosystem Sciences, Desert Research Institute, Reno, NV, USA \\ ${ }^{2}$ Institute for the Environment, University of North Carolina, Chapel Hill, NC, USA \\ ${ }^{3}$ Institute for Sustainable Cities, City University of New York, New York, NY, USA
}

Correspondence to: G. Tang (tangg2010@gmail.com)

Received: 24 September 2013 - Published in Hydrol. Earth Syst. Sci. Discuss.: 17 October 2013

Revised: - Accepted: 2 March 2014 - Published: 11 April 2014

\begin{abstract}
The cycling of carbon (C) in terrestrial ecosystems is closely coupled with the cycling of water. An important mechanism connecting ecological and hydrological processes in terrestrial ecosystems is lateral flow of water along landscapes. Few studies, however, have examined explicitly how consideration of water routing affects simulated water and $\mathrm{C}$ dynamics in terrestrial ecosystems. The objective of this study is to explore how consideration of water routing in a process-based hydro-ecological model affects simulated water and $\mathrm{C}$ dynamics. To achieve that end, we rasterized the regional hydro-ecological simulation system (RHESSys) and employed the rasterized RHESSys (R-RHESSys) in a forested watershed. We performed and compared two contrasting simulations, one with and another without water routing. We found that R-RHESSys was able to correctly simulate major hydrological and ecological variables regardless of whether water routing was considered. When water routing was considered, however, soil water table depth and saturation deficit were simulated to be greater and spatially more heterogeneous. As a result, water (evaporation, transpiration, and evapotranspiration) and C (forest productivity, soil autotrophic and heterotrophic respiration) fluxes also were simulated to be spatially more heterogeneous compared to the simulation without water routing. When averaged for the entire watershed, the three simulated water fluxes were greater while $\mathrm{C}$ fluxes were smaller under simulation considering water routing compared to that ignoring water routing. In addition, the effects of consideration of water routing on simulated $\mathrm{C}$ and water dynamics were more apparent in dry conditions. Overall, the study demonstrated that consideration of water routing enabled R-RHESSys to better
\end{abstract}

capture our preconception of the spatial patterns of water table depth and saturation deficit across the watershed. Because soil moisture is fundamental to the exchange of water and $\mathrm{C}$ fluxes among soil, vegetation and the atmosphere, ecosystem and $\mathrm{C}$ cycle models therefore need to explicitly represent water routing in order to accurately quantify the magnitude and patterns of water and $\mathrm{C}$ fluxes in terrestrial ecosystems.

\section{Introduction}

The cycling of carbon (C) in terrestrial ecosystems is closely coupled with the cycling of water. Plants need water to survive, and thus, the distribution, composition, and structure of plant communities are directly influenced by spatial patterns of available water (Band, 1993; Band et al., 1993; Caylor et al., 2005; Ivanov et al., 2008). An important mechanism that connects ecological and hydrological processes in terrestrial ecosystems is lateral water flow along landscapes. Lateral water flow can redistribute water and nutrients through space, which affects plant establishment and growth (Band et al., 1993); leaf phenology (Asbjornsen et al., 2011); ecosystem structure and function (Wang et al., 2009); and soil biogeochemical processes, such as organic matter decomposition (Ju et al., 2006; Riveros-Iregui et al., 2011). For example, studies have demonstrated that lateral water flow and connectivity act as important determinants of ecological patterns and processes in heterogeneous landscapes (Band et al., 1993; Sponseller and Fisher, 2008), and contribute to changes in surface water, energy, nutrients, and $\mathrm{C}$ in space 
(Pockman and Small, 2010). In mountainous catchments, Hwang et al. (2012) found that lateral water flow can produce important patterns in water and nutrient fluxes as well as stores, which influences the long-term spatial development of forest ecosystems. Riveros-Iregui et al. (2011) suggested that landscape-imposed redistribution of soil water is a major cause for distinct variation of growing-season soil $\mathrm{CO}_{2}$ efflux within small subalpine watersheds.

Hydrological connectivity via lateral water flow plays important roles in the transport of water, nutrients and sediments at catchment scales (Smith et al., 2010). Correspondingly, distributed hydrology models (DHM) that simulate lateral water flow and its spatial connectivity along landscapes or among simulated grids have been developed increasingly in recent years (Lane et al., 2009). These models - such as DHSVM (Wigmosta et al., 1994) and RHESSys (Band et al., 1993; Tague and Band, 2004) - couple runoff generation and water routing mechanisms and thus are able to explicitly simulate the effects of topographic and subsurface heterogeneities on downslope redistribution of water and nutrients (Doten et al., 2006). In fact, DHMs are used widely to identify saturated areas that produce runoff and non-point source pollution (Gérard-Marchanti et al., 2006), evaluate irrigation systems (Singh et al., 2006), and examine flood potential associated with disturbances such as deforestation (Doten et al., 2006). The representation of soil moisture variability and water routing processes at grid cell level in DHMs also enables these models to account for spatial variability of runoff-generating mechanisms and infer model parameterization from distributed geospatial data such as geology, topography, soils, and land cover (Wang et al., 2011). These advantages greatly contributed to the accuracy of hydrologic forecasting (Smith et al., 2012).

Despite the fact that lateral water flow redistributes water and nutrients in space and thus affects ecosystem structure and function as well as the cycling of water and C, the representation of lateral water flow and its spatial connectivity may not be adequate in existing ecosystem and $\mathrm{C}$ cycle models. For example, Riveros-Iregui et al. (2011) indicated that the robust implementation of the lateral redistribution of soil water into biogeochemical models is often lacking. Chen et al. (2005) argued that most $\mathrm{C}$ cycle models at regional and global scales use bucket models to estimate soil moisture and ignore lateral exchanges of water among simulated units. The causes for such inadequacy are (i) lack of detailed information on how lateral water flow may affect vegetation, water, and $\mathrm{C}$ dynamics in terrestrial ecosystems, and (ii) increased burden of computing when water routing is included in the model's simulation (Ju et al., 2006). This inadequacy, however, is likely to hinder better quantification of the spatial heterogeneity and complex linkages of hydrological, ecological, and biogeochemical processes in terrestrial ecosystems.

Furthermore, mountain forests account for about $23 \%$ of the earth's forest cover and play an important role in modulating global cycling of water and C (Price et al., 2011).
Given the elevational gradient in mountain forests plus gravity, lateral water flow - such as subsurface lateral flow along slopes - is common in humid mountain forests (Ridolfi et al., 2003). In semi-arid and arid ecosystems, surface lateral flow also occurs when rainfall intensity exceeds the infiltration capacity of dry soils (Kim and Eltahir, 2004) or on topographically flat ground if the presence of the vegetation patch creates a contrast in infiltration rate (Thomspon et al., 2011). The universality and significance of lateral water flow in terrestrial ecosystems suggest that it should not be overlooked by ecosystem and $\mathrm{C}$ cycle models. A better understanding of how lateral water flow and its spatial connectivity may affect water and $\mathrm{C}$ dynamics is therefore important for accurate quantification of terrestrial water and $\mathrm{C}$ budgets as well as sustainable management of water and forest resources (e.g., Wang et al., 2011).

The overall objectives of this study are to investigate (i) how consideration of water routing in a process-based, hydro-ecological model affects simulated water and $\mathrm{C}$ dynamics in terrestrial ecosystems; and (ii) if effects of consideration of water routing on simulated $\mathrm{C}$ and water dynamics are more remarkable in dry conditions. Toward these ends, we rasterized a regional hydro-ecological model designed to simulate integrated water, $\mathrm{C}$ and nutrient dynamics at watershed and regional scales. The rasterization aimed to (i) remove the model's hierarchical structure so that all hydrological and ecological processes would be simulated at the individual cell level; and (ii) add a new control interface so that the water routing algorithm built into the model could be switched on or off. These modifications allowed us to keep all model parameters and their parameterization identical between two predesigned contrasting simulations: with vs. without water routing. In turn, this helped reduce the uncertainty of model-based comparisons that can result from differences in model structure, parameters, and parameterization - as commonly encountered in model-based intercomparison studies. Based on the rasterized model, we performed two contrasting simulations for each of the two contrasting forcing scenarios: "wet" vs. "dry". We compared simulated soil water table depth and saturation deficit, evaporation, transpiration, evapotranspiration, forest productivity, and soil respiration from these simulations. Findings gained from these comparisons provide insights into the future development of ecosystem and $\mathrm{C}$ cycle models for terrestrial ecosystems.

\section{Material and data}

\subsection{Study area}

The Biscuit Brook (hereafter Biscuit) watershed in the Catskill Mountain region of New York State (Fig. 1) was selected as the study region. This watershed is relatively humid, with annual total precipitation of about $145 \mathrm{~cm}$ and annual 


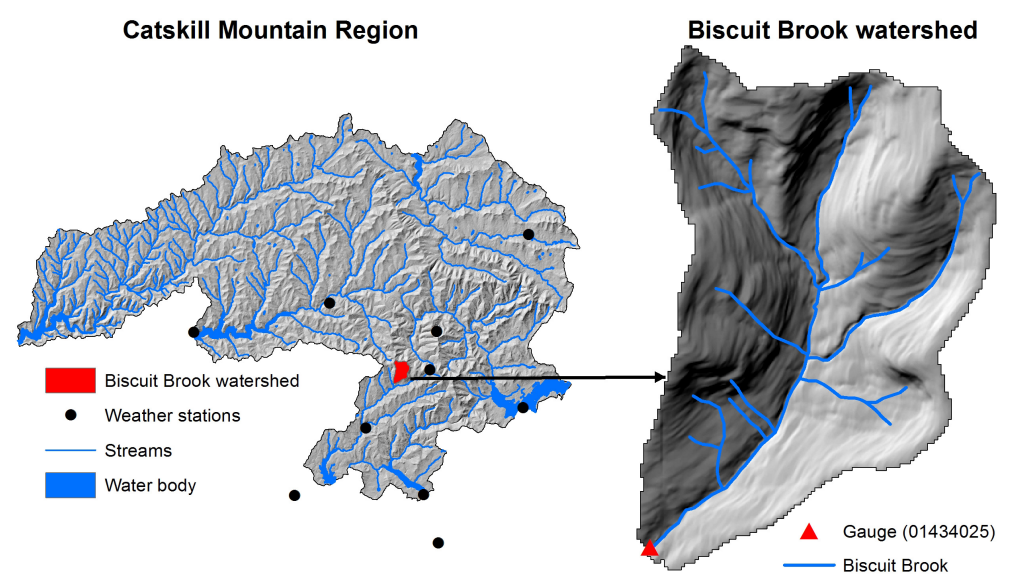

Fig. 1. The location of the Biscuit Brook watershed (red area) and the United States Geological Survey gauge station within the Catskill Mountain region of New York State. The map on the left depicts boundaries of the West of Hudson watershed and reservoirs of the New York City water supply system. The black points are 10 Cooperative Observer Program weather stations used to derive meteorological data for the watershed.

mean temperature about $4.4^{\circ} \mathrm{C}$. The slopes vary from 0.04 to $37^{\circ}$, and the maximum slope length is $4.73 \mathrm{~km}$ in a northeast to southwest direction (Fig. 1). We selected this watershed as the study region because (i) long-term historical streamflow observations from one USGS gauge station (01434025) for this watershed are available to calibrate and evaluate model simulations; (ii) this watershed is forested and thus well suited for investigating the linkages between ecological and hydrological processes; (iii) there are no human-related land use activities; and (iv) the watershed has spatially variable terrain with elevation ranging from 270 to $1270 \mathrm{~m}$, providing a natural hydro-ecological laboratory to examine the effects of lateral water flow and its spatial connectivity on water, $\mathrm{C}$ and vegetation dynamics in terrestrial ecosystems.

\subsection{Rasterizing the regional hydro-ecological simulation system}

The Regional Hydro-Ecological Simulation System (RHESSys, Tague and Band, 2004) is a process-based hydro-ecological model designed for simulating integrated water, $\mathrm{C}$ and nutrient dynamics, as well as vegetation growth at watershed and regional scales. Although RHESSys is capable of being run in fully distributed mode, its hierarchical framework requires that some initial-state variables associated with the spatial hierarchy of basins, hillslopes, and zones be arranged per a prescribed template. In this study, we further rasterized RHESSys (version 5.12) in an attempt to remove the model's hierarchical structure. The rasterized RHESSys (hereafter R-RHESSys) adopted almost all features of its predecessor except for (i) exclusion of the hierarchical model framework of RHESSys, and (ii) modification of the user interface for controlling model simulation. The exclusion of the hierarchical structure in RRHESSys caused the basin, hillslope, and zone hierarchical structures existing in RHESSys to exist no longer. As a result, arrangement of some initial-state variables according to the prescribed template (i.e., the World file in RHESSys) was no longer needed. In addition, R-RHESSys excluded the TOPMODEL (Beven and Kirkby, 1979) embedded in its predecessor but retained the explicit water-routing algorithm (Wigmosta et al., 1994) for simulating surface and subsurface lateral flow as well as movement of solutes through space. The water routing algorithm in R-RHESSys can be switched on or off and thus provides users two ways (i.e., with vs. without water routing) to quantify C, water, and nutrient dynamics in terrestrial ecosystems. As in its predecessor, surface and subsurface lateral flow for stream-type patches are channelized in R-RHESSys.

Because specific algorithms for $\mathrm{C}$, water, and nutrient dynamics are maintained mostly as in Tague and Band (2004), we briefly introduced calculation of subsurface and surface flow that was slightly modified for reference. In RRHESSys, the saturated subsurface flow $\left(\mathrm{SF}_{a \rightarrow b}\right)\left(\mathrm{m} \mathrm{day}^{-1}\right)$ from patch $a$ to $b$ is calculated as follows:

$$
\mathrm{SF}_{a \rightarrow b}=\left\{\begin{array}{cc}
\delta \times \gamma \times\left(e^{-s / m}-e^{-s_{\max / m}}\right) & s \geq 0 \\
\delta \times \gamma \times\left(e^{-s /(3.5 \mathrm{~m})}-e^{-s_{\max } / m}\right) & s<0,
\end{array}\right.
$$

where $s(\mathrm{~m})$ is saturation deficit in patch $a ; m$ (dimensionless) is the decay rate of soil hydraulic conductivity with depth in patch $a ; s_{\max }(\mathrm{m})$ is the water equivalent of soil depth; $\delta$ (dimensionless) is the empirical sensitivity parameter with a value of 1.2 when water routing is considered and a value of 0.16 when water routing is ignored. The values 1.2 and 0.16 are based on model calibrations (see below); and $\gamma\left(\mathrm{m} \mathrm{day}^{-1}\right)$ is the percent of subsurface flow going from patch $a$ to patch $b$. It is expressed as

$\gamma=K_{\mathrm{sat} 0} \times \tan \beta_{a \rightarrow b} \times W_{a \rightarrow b}$, 
where $K_{\text {sat0 }}\left(\mathrm{m} \mathrm{day}^{-1}\right)$ is saturated hydraulic conductivity at the surface; $\beta$ (degree) is the local slope from patch $a$ to patch $b$; and $W$ (dimensionless) is the flow width from patch $a$ to patch $b$. The flow widths are assumed to be 0.5 times the grid size for cardinal directions and 0.354 times the grid size for diagonal directions (Quinn et al., 1991; Tague and Band, 2004).

The saturation overland flow $\left(\mathrm{RF}_{a}\right)$ for patch $a$ is expressed as follows:

$\mathrm{RF}_{a}=\max \left(\mathrm{RS}+U_{\mathrm{satS}}-s, 0.0\right)$,

where RS (m) is soil water storage in the root zone layer; and $U_{\text {sats }}(\mathrm{m})$ is soil water storage in the unsaturated soil layer.

When water routing is considered in R-RHESSys, the saturated subsurface flow input from the upslope patch $a$ (Eq. 1) is added to the downslope patch $b$ and accounted for in patch $b$ 's local water budget. When routing is turned off, Eq. (1) is still used to calculate subsurface flow out of each patch. However, rather than being routed to downslope patches, the subsurface outflows from all patches are summed and assumed to flow out of the basin as the baseflow component of streamflow. The value of the sensitivity parameter $\delta$ in Eq. (1) for the non-routing case is reduced to reflect the change in function of this parameter from a lateral flow between patches adjustment to what is effectively a baseflow recession coefficient. The other difference between routing and non-routing is that with routing on, the surface flow generated by Eq. (3) is routed following the same topology as subsurface flow and is allowed to re-infiltrate along its flow path, whereas with no routing, the surface flow generated by Eq. (3) for all patches is summed and assumed to flow out of the basin as the runoff component of streamflow.

\subsection{Meteorological data}

Time series of daily maximum and minimum temperature $\left({ }^{\circ} \mathrm{C}\right)$ as well as total precipitation $(\mathrm{mm})$ are required to run R-RHESSys. Because there is no weather station located in the Biscuit watershed, our climate data for the period 1961-2008, a period having as long as possible available climate records and preselected for model spin-up simulation, were derived from 10 Cooperative Observer Program stations (COOP) (Fig. 1). Specifically, daily climate data for each day in each year for the watershed were estimated using the ordinary Kriging interpolation approach (Goovaerts, 1998). Before interpolation, daily records of temperatures that exceeded the long-term (1961-2008) mean of all available records from that station by four standard deviations or greater were manually removed on a case-by-case basis (e.g., Tang and Arnone III, 2013). In addition, local lapse rates of $-0.0085^{\circ} \mathrm{C} \mathrm{m}^{-1}$ for daily maximum temperature, $-0.0054^{\circ} \mathrm{C} \mathrm{m}^{-1}$ for daily minimum temperature, and $0.0014 \mathrm{~mm} \mathrm{~m}^{-1}$ for daily precipitation were used to adjust temperature and orographic precipitation changes along the elevation gradient in the study sites. Figure S1 in the
Supplement shows examples of interpolated daily maximum and minimum temperatures as well as precipitation for the Biscuit watershed in July 1994.

\subsection{Land cover, soil and elevation data}

The land cover data used to pre-define vegetation types for the Biscuit watershed were based on the National Land Cover Dataset 1992 (NLCD 1992; http://landcover.usgs.gov/ usmap.php). The NLCD 1992 data were derived from Landsat Thematic Mapper satellite data at $30 \mathrm{~m}$ spatial resolution and classified land covers into 21 types for the United States (Vogelmann et al., 1998a, b). For the Biscuit watershed, only three types exist in NLCD 1992: evergreen, deciduous and mixed forests. Our soil texture data at $30 \mathrm{~m}$ spatial resolution were derived from the digital Soil Survey Geographic Database (http://soils.usda.gov/). We classified soil in the Biscuit watershed into four types: sandy loam, loamy skeleton, silt loam and rocky (Fig. S1d in the Supplement). Soiltexture-related parameters and their parameterization are in Table 1. The USGS National Elevation Dataset at $1 \mathrm{arcsec}$ spatial resolution (about $30 \mathrm{~m}$ ) was used in this study.

\subsection{Modeling protocol, model simulation, calibration, and evaluation}

Given that climate in the Biscuit watershed is relatively humid and precipitation has no distinct dry and wet cycles, we performed four simulations under two climate forcing scenarios: one wet and one dry. Under the wet scenario, time series of daily climate data for the period 1961-2008 were directly used without modification. Under the dry scenario, we set time series of daily precipitations for days in May, June, July and August in 1995 at zero while keeping others identical to those under the wet scenario. For each of the two scenarios, the two contrasting simulations (i.e., with vs. without water routing) were performed, respectively.

Our initial simulations under the wet scenario suggested that soil water table depth, leaf area index (LAI) and forest productivity tended to reach the equilibrium state after 50 simulation-years. In contrast, soil $\mathrm{C}$ took more than 200 simulation-years to reach the equilibrium state (Fig. S2 in the Supplement). In order to have vegetation and soil $\mathrm{C}$ reach equilibrium state with long-term local climate, we spun up R-RHESSys for 240 years repeatedly using 48 -year (1961-2008) daily-step meteorological data. After spin-up simulations, we continued to run R-RHESSys for an additional 48 years using data from 1961 to 2008 . This modeling protocol applied to all four simulations under both wet and dry forcing scenarios.

Based on results under the wet scenario, we calibrated RRHESSys for the period 1992-1993 and evaluated it for the period 1994-1995. The period 1992-1995 was selected because observed climate records in this period from $10 \mathrm{COOP}$ stations were more consistent than during other periods. This 
Table 1. Major soil parameters and their parameterizations used in this study.

\begin{tabular}{llllll}
\hline & & \multicolumn{4}{c}{ Soil texture } \\
\cline { 3 - 6 } Variables & Unit & $\begin{array}{l}\text { Sandy } \\
\text { loam }\end{array}$ & $\begin{array}{l}\text { Silt } \\
\text { loam }\end{array}$ & $\begin{array}{l}\text { Loamy } \\
\text { skeleton }\end{array}$ & Rocky \\
\hline$K_{\text {sat_0 }}^{*}$ & m day $^{-1}$ & 89.05 & 48.62 & 48.36 & 109.56 \\
$m^{*}$ & DIM & 0.09 & 0.12 & 0.13 & 0.09 \\
Porosity & $\%$ & 0.435 & 0.410 & 0.451 & 0.485 \\
Porosity decay & DIM & 4000 & 4000 & 4000 & 4000 \\
Pore size index (PSI) & DIM $(0-1)$ & 0.204 & 0.189 & 0.186 & 0.228 \\
PSI air entry & $\%$ & 0.218 & 0.386 & 0.478 & 0.480 \\
Soil depth & $\mathrm{m}$ & 5.0 & 5.2 & 4.8 & 5.0 \\
Active zone depth & $\mathrm{m}$ & 10 & 10.0 & 10.0 & 10.0 \\
Maximum energy capacity & ${ }^{\circ} \mathrm{C}$ & -10. & -10. & -10. & -10. \\
Albedo & $\mathrm{DIM}$ & 0.258 & 0.253 & 0.320 & 0.200 \\
Sand & $\%$ & 0.70 & 0.20 & 0.80 & 0.75 \\
Clay & $\%$ & 0.10 & 0.15 & 0.02 & 0.05 \\
Silt & $\%$ & 0.20 & 0.65 & 0.18 & 0.20 \\
\hline
\end{tabular}

${ }^{*} K_{\mathrm{sat} \_} 0$ is saturated hydraulic conductivity at the surface; $m$ is the decay rate of hydraulic conductivity with depth. $K_{\text {sat } \_0}$ and $m$ were manually calibrated against observed streamflow and derived baseflow at the USGS gauge station.

can minimize the effects of the quality of atmospheric forcing data on simulated water and $\mathrm{C}$ dynamics. Correspondingly, model calibration and evaluation for each of the two pre-specified periods were performed for the two contrasting simulations under the wet scenario, respectively.

To investigate how consideration of water routing may affect simulated $\mathrm{C}$ and water dynamics, monthly average daily values of major hydro-ecological variables in July of 1994 from the two contrasting simulations under the wet scenario were compared. The July of 1994 was selected because temperature in July is generally higher than in other months and thus the effects of consideration of water routing on simulated water and $\mathrm{C}$ dynamics as well as vegetation growth were assumed to be more detectable. To test if effects of consideration of water routing on simulated $\mathrm{C}$ and water dynamics are more remarkable in dry conditions, we compared the differences in simulated monthly values of major hydro-ecological variables in 1995 between the wet and dry scenarios.

\section{Results}

\subsection{Calibration and evaluation of simulated streamflow and baseflow}

Figure 2 shows the time series of simulated daily streamflow and baseflow for the Biscuit Brook in the watershed for the calibration period 1992-1993 and the evaluation period 1994-1995. For the calibration period, the calculated NashSutcliffe coefficients (NS; Nash and Sutcliffe, 1970) is 0.58 for streamflow (Fig. 2a) and 0.63 for baseflow (Fig. 2b) under the simulation that considered water routing. In contrast, the calculated NS is 0.61 for streamflow (Fig. 2c) and 0.74 for baseflow (Fig. 2d) for the simulation that neglected water routing. For the evaluation period, the calculated NS was more than 0.57 for both streamflow and baseflow regardless of whether or not water routing was considered (Fig. 2a-d). In addition, the simulated average daily streamflow for the evaluation period 1994-1995 approximated each other between the two simulations ( 2.54 vs. $2.50 \mathrm{~mm} \mathrm{day}^{-1}$ ). The difference in average daily streamflow between model simulations and observation was less than $1.25 \%$ under both simulations. These statistics (Table S1 in the Supplement) suggested that R-RHESSys was able to accurately simulate daily streamflow and baseflow regardless of whether water routing was considered.

\subsection{Comparison of simulated soil water table depth and saturation deficit}

When water routing was considered, the simulated depth to the soil water table ranged from 0.15 to $2.92 \mathrm{~m}$ among cells and averaged $1.20 \mathrm{~m}$ for the entire watershed. In contrast, when water routing was ignored, the simulated depth ranged from 0.02 to $1.20 \mathrm{~m}$ among cells, and averaged $0.72 \mathrm{~m}$ for the entire watershed. In other words, the simulated water table depth was spatially more variable when water routing was simulated as indicated by the calculated standard deviations for soil water table depth among cells (Table 2 and Fig. 3a vs. b). A similar situation applied to the simulated saturation deficit, which had a wider range from 0.08 to $1.42 \mathrm{~m}$ under simulation with water routing but a narrower range from 0.01 to $0.54 \mathrm{~m}$ under simulation without water routing (Table 2). The simulated saturation deficit also was spatially more variable under simulation with water routing than that 
Table 2. Comparison of simulated hydrological and ecological variables between the two contrasting simulations: with vs. without water routing.

\begin{tabular}{|c|c|c|c|c|c|}
\hline Variables & $\begin{array}{l}\text { Water } \\
\text { routing }\end{array}$ & Minimum & Maximum & Mean & STD \\
\hline \multirow[t]{2}{*}{ Water table depth (m) } & Yes & 0.15 & 2.92 & 1.20 & 0.40 \\
\hline & No & 0.02 & 1.20 & 0.72 & 0.19 \\
\hline \multirow[t]{2}{*}{ Saturation deficit (m) } & Yes & 0.08 & 1.42 & 0.54 & 0.17 \\
\hline & No & 0.01 & 0.54 & 0.33 & 0.08 \\
\hline \multirow[t]{2}{*}{ Evaporation (mm) } & Yes & 0.22 & 3.11 & 0.87 & 0.42 \\
\hline & No & 0.52 & 1.05 & 0.74 & 0.05 \\
\hline \multirow[t]{2}{*}{ Plant transpiration (mm) } & Yes & 0.00 & 3.86 & 1.41 & 0.49 \\
\hline & No & 0.92 & 1.95 & 1.35 & 0.13 \\
\hline \multirow[t]{2}{*}{ Evapotranspiration (mm) } & Yes & 0.28 & 6.65 & 2.27 & 0.79 \\
\hline & No & 1.44 & 2.99 & 2.09 & 0.18 \\
\hline \multirow[t]{2}{*}{$\mathrm{NPP}\left(\mathrm{gC} \mathrm{m}^{-2} \mathrm{day}^{-1}\right)$} & Yes & 0.01 & 5.79 & 3.33 & 0.84 \\
\hline & No & 2.50 & 5.79 & 3.60 & 0.17 \\
\hline \multirow{2}{*}{$\mathrm{RA}\left(\mathrm{gC} \mathrm{m}^{-2} \mathrm{day}^{-1}\right)$} & Yes & 0.00 & 0.97 & 0.58 & 0.18 \\
\hline & No & 0.35 & 0.97 & 0.63 & 0.08 \\
\hline \multirow[t]{2}{*}{$\mathrm{RH}\left(\mathrm{gC} \mathrm{m}^{-2} \mathrm{day}^{-1}\right)$} & Yes & 0.01 & 1.3 & 0.75 & 0.20 \\
\hline & No & 0.44 & 1.3 & 0.84 & 0.08 \\
\hline
\end{tabular}
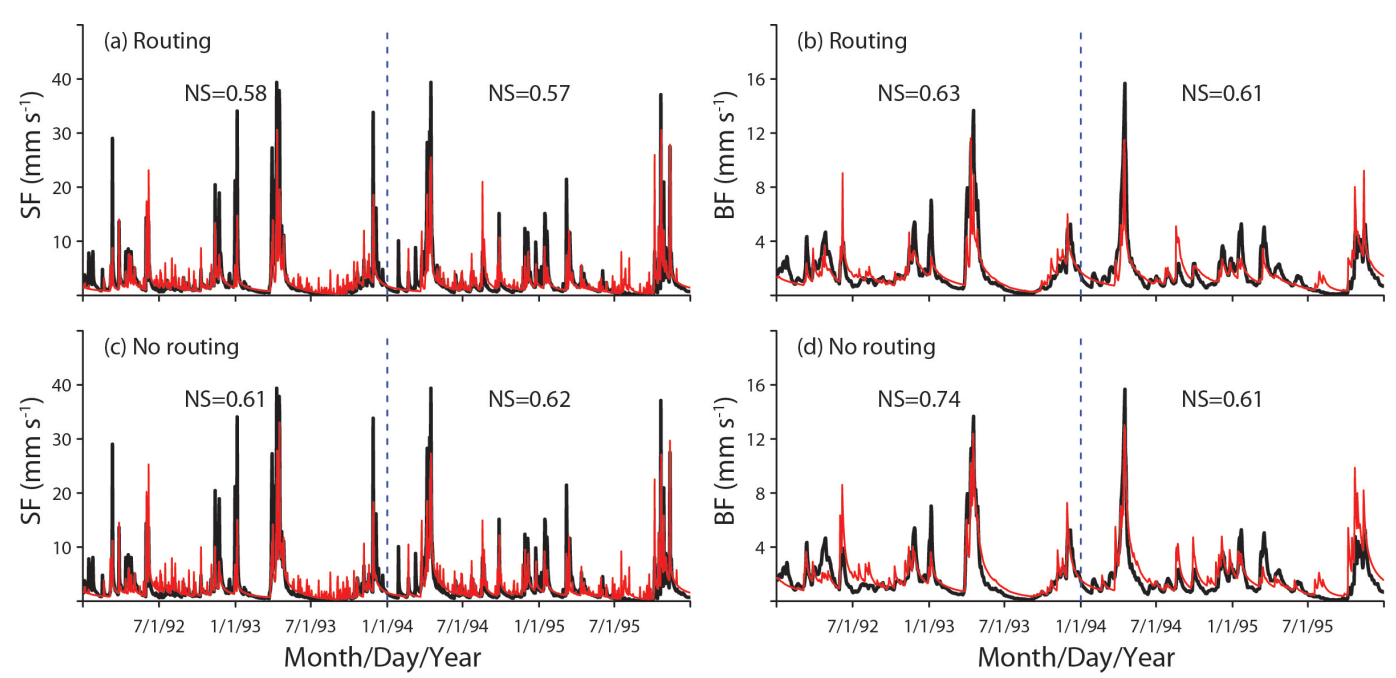

Fig. 2. Calibration (for the period 1 January 1992-31 December 1993) and evaluation (for the period 1 January 1994-31 December 1995) of R-RHESSys simulated daily streamflow (SF) and baseflow (BF) (solid red line) against observed/derived data (solid black line). Simulations in (a) and (b) considered water routing while simulations in (c) and (d) ignored water routing. NS is short for the Nash-Sutcliff coefficient. The blue-dashed line represents 1 January 1994.

without water routing (Fig. 3d vs. e), as indicated by the standard deviations for saturation deficit among cells (Table 2). Further comparison suggested that water table depth and saturation deficit were about $0.5 \mathrm{~m}$ (for water table) and $0.2 \mathrm{~m}$ (for saturation deficit) greater in the hills or ridges of the watershed when water routing was considered. In the valleys or flat areas, however, there are regions where the simulated water table depth and saturation deficit were smaller when water routing was considered compared to the simulation ignoring water routing (Fig. 3c and f). Spatially, deeper water table depth and higher saturation deficit were simulated to occur mostly at upslope areas (Fig. 3a and d) when water routing was considered. This situation, however, did not always apply to simulations ignoring water routing, under which water table depth and saturation deficit were found to be greater at steeper slopes (Fig. 3b and e).

\subsection{Comparison of simulated evaporation, transpiration, and evapotranspiration}

Compared to the simulation ignoring water routing, simulated monthly average daily evaporation, transpiration, and 

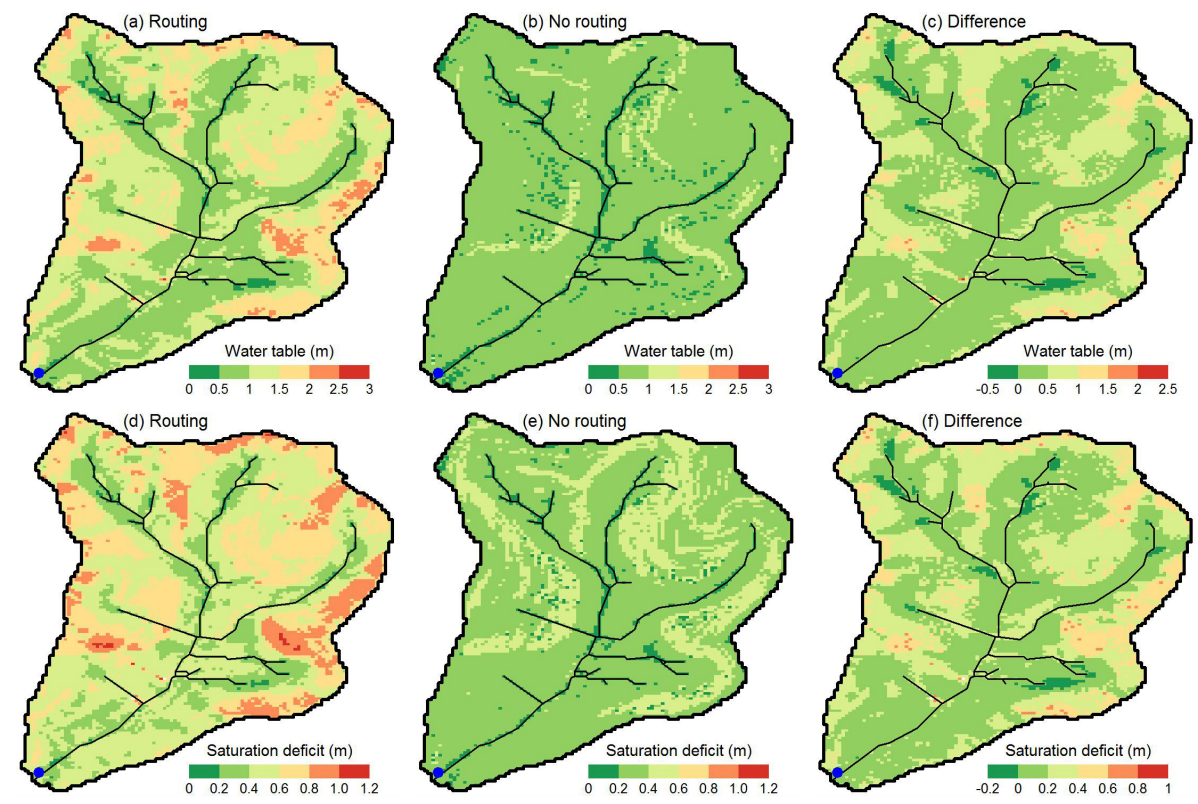

Fig. 3. Comparison of simulated monthly average daily soil water table depth and saturation deficit in July 1994 between the two contrasting simulations: (a) and (d) considered water routing while (b) and (e) ignored water routing. (c) and (f) show differences in simulated soil water table depth and saturation deficit between the two contrasting simulations.

actual evapotranspiration (ET) with water routing had a wider range among cells. For example, monthly average daily evaporation for July 1994 was simulated to vary from 0.22 to $3.11 \mathrm{~mm} \mathrm{day}^{-1}$ among cells under simulation with water routing. In contrast, evaporation had a narrower range from 0.52 to $1.05 \mathrm{~mm} \mathrm{day}^{-1}$ under the simulation without water routing (Table 2). When averaged for the entire watershed, monthly average daily evaporation, plant transpiration, and ET were $18 \%$ (0.87 vs. $0.74 \mathrm{~mm}), 4 \%$ $(1.41$ vs. $1.35 \mathrm{~mm})$ and $9 \%(2.27$ vs. $2.09 \mathrm{~mm})$ greater, respectively, under simulation considering water routing than that ignoring water routing (Table 2). In addition, regardless of the actual magnitudes of simulated water fluxes, the spatial patterns of evaporation, transpiration, and ET were modeled to be more variable under simulation considering water routing than that ignoring water routing, largely because extreme high and low values of evaporation, transpiration and ET were simulated to occur under the simulation with water routing (Fig. S3 in the Supplement and Fig. 4). Spatially, the effects of considering water routing on simulated evaporation, transpiration, and ET can be either positive or negative compared to the simulation neglecting water routing (Fig. S3 in the Supplement).

\subsection{Comparison of simulated forest net primary productivity (NPP)}

At the individual cell level, simulated monthly average daily NPP in July, 1994 (when ignoring water routing) ranged from 2.50 to $5.79 \mathrm{gC} \mathrm{m}^{-2}$, narrower than results from the

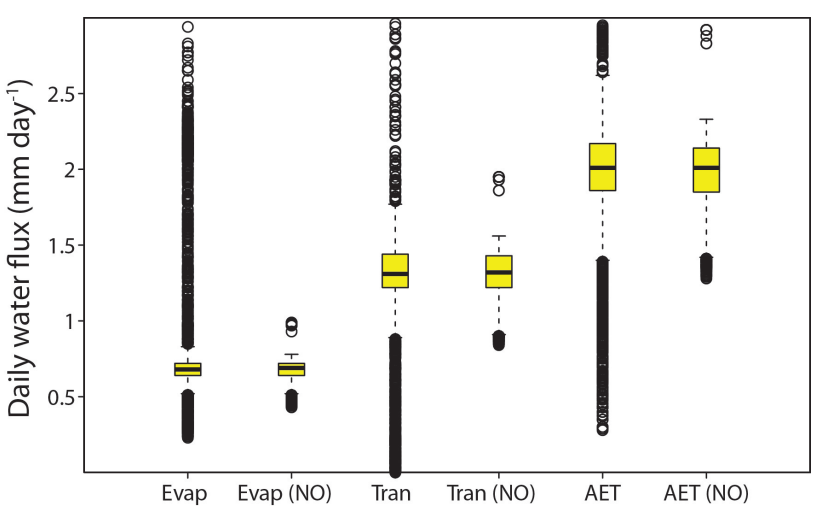

Fig. 4. Comparison of simulated monthly average daily evaporation (evap), transpiration (Tran), and actual evapotranspiration (AET) in July, 1994 between the two simulations with and without (indicated by "NO") consideration of water routing.

simulation considering water routing, which ranged from 0.10 to $5.79 \mathrm{gC} \mathrm{m}^{-2}$ among cells. In addition, although the pattern of simulated NPP was extremely similar in most areas of the watershed between the two simulations (Fig. 5a and b), simulated monthly average daily NPP among cells was spatially more variable when water routing was considered, as suggested by the calculated standard deviations for NPP among cells (Table 2). When averaged for the entire watershed, the simulated monthly average daily NPP was $8 \%$ (3.33 vs. $3.60 \mathrm{gC} \mathrm{m}^{-2}$ ) lower under simulation considering water routing than that ignoring water routing (Table 2). Nevertheless, the simulated maximum NPP between 

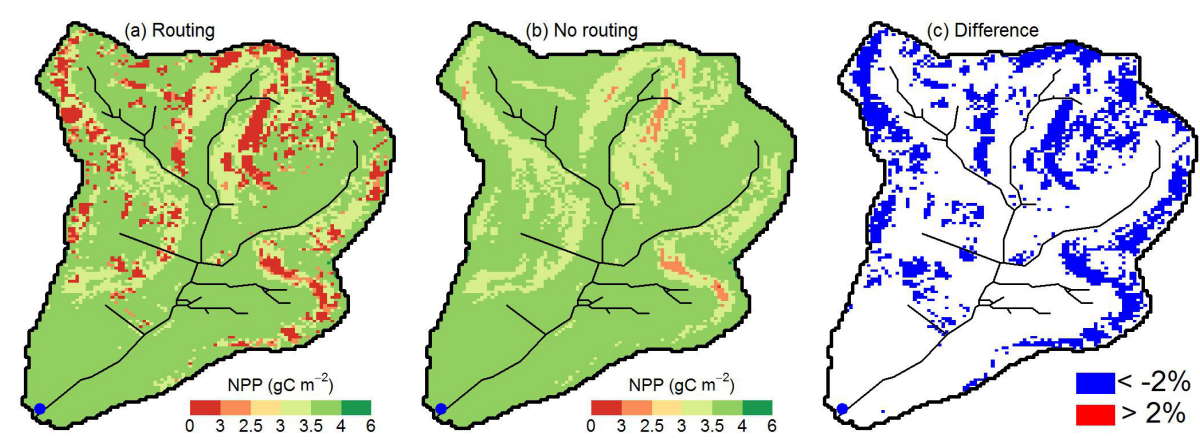

Fig. 5. Comparison of simulated monthly average daily net primary productivity (NPP) in July 1994 between the two simulations: (a) considering water routing and (b) ignoring water routing. (c) Shows percentage difference between (a) and (b) divided by the result from simulation (a) considering water routing. The white areas show no significant differences.

the two simulations was identical $\left(5.79 \mathrm{gC} \mathrm{m}^{-2}\right)$, although there were regions where simulated NPP was distinctly lower $\left(<3.0 \mathrm{gC} \mathrm{m}^{-2}\right)$ under the simulation considering water routing than that ignoring water routing $\left(>3.0 \mathrm{gC} \mathrm{m}^{-2}\right)$. Overall, the simulation that neglected water routing had a tendency to overestimate forest NPP in ridges of the watershed or areas with steeper slopes (Fig. 5c).

\subsection{Comparison of simulated soil autotrophic and heterotrophic respiration}

Simulated monthly averaged daily soil autotrophic respiration (RA) in July 1994 ranged from 0.0 to $0.97 \mathrm{gC} \mathrm{m}^{-2}$ under the simulation with water routing. This range was slightly broader than that from the simulation without water routing, which ranged from 0.35 to $0.97 \mathrm{gC} \mathrm{m}^{-2}$ (Table 2). When averaged for the entire watershed, monthly average daily soil RA was $8 \%$ ( 0.58 vs. $0.63 \mathrm{gC} \mathrm{m}^{-2}$, Table 2$)$ lower under simulation with water routing than that without water routing. In addition, although the spatial pattern of simulated soil RA across the watershed was extremely similar in most areas between the two simulations (Fig. 6a and b), there were patches where simulated soil RA was much lower when water routing was considered (Fig. 6c). Overall, neglect of water routing has the potential to cause R-RHESSys to overestimate soil RA, while such overestimates mainly occur in areas of steeper slopes or near the ridges of the watershed (Fig. 6c). Similarly, simulated soil heterotrophic respiration (RH) had a wider range from 0.01 to $1.3 \mathrm{gC} \mathrm{m}^{-2}$ under simulation with water routing and a narrower range from 0.44 to $1.3 \mathrm{gC} \mathrm{m}^{-2}$ under the simulation without water routing (Table 2). The spatial patterns of simulated soil RH were more variable under simulation with water routing than that without water routing (Fig. 6d and e). Besides, when averaged for the entire watershed, monthly average daily soil RH was $11 \%$ (0.75 vs. 0.84$)$ lower under the simulation considering water routing than that ignoring water routing. Differing from soil RA, the effects of water routing on soil RH can be either positive or negative when compared to the simulation without water routing (Fig. 6f). The difference in simulated soil $\mathrm{RH}$ between the two simulations ranged from -0.8 to $0.12 \mathrm{gC} \mathrm{m}^{-2}$ across cells.

\subsection{Comparison of the differences (with vs. without routing) in monthly values of hydro-ecological variables between the wet and dry scenarios}

Figure 7 shows comparisons of the simulated differences (with vs. without water routing) in monthly values of $\mathrm{C}$ and water dynamics in 1995 between the wet and dry scenarios. When averaged for the entire watershed, the magnitude of the differences in monthly average water table depth and saturation deficit was not distinct for months before July between the two scenarios, while the differences diverged for months after July: greater under the wet and smaller under the dry scenario (Fig. 7a and b). For water fluxes, the absolute magnitude of the differences in monthly transpiration and AET was greater under the dry scenario for May, June, July, August, and September, and bottomed in August (Fig. 7d and e). In other months, the magnitude of the differences in monthly transpiration and ET approximated each other between the two scenarios, especially for transpiration (Fig. 7e). However, this pattern of differences in monthly transpiration and AET did not apply to evaporation (Fig. 7c). For C fluxes, the absolute magnitude of the difference in monthly average NPP, soil RA, and RH was greater under the dry scenario for May, June, July, August, and September, and bottomed in August (Fig. 7f-h). In other months, the simulated differences in the three $\mathrm{C}$ fluxes approximated each other between the two scenarios. These results indicated that consideration of water routing has greater effects on simulated water and C dynamics in dry conditions. 

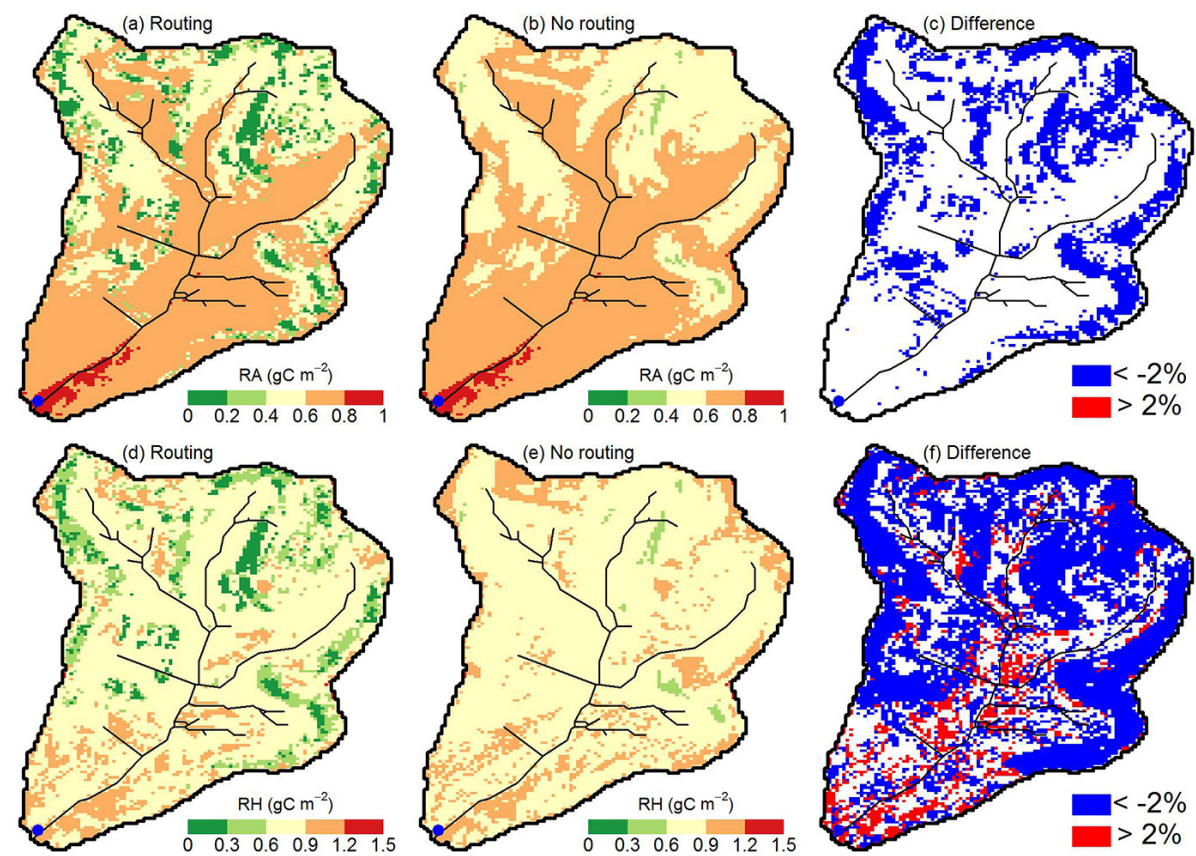

Fig. 6. Comparison of simulated monthly average daily soil autotrophic (RA) and heterotrophic respiration (RH) in July 1994 between the two simulations: (a) and (d) considering water routing while (b) and (e) ignoring water routing. (c) and (f) show percentage differences between the two simulations divided by results from the simulation considering water routing. The white areas show no significant differences.
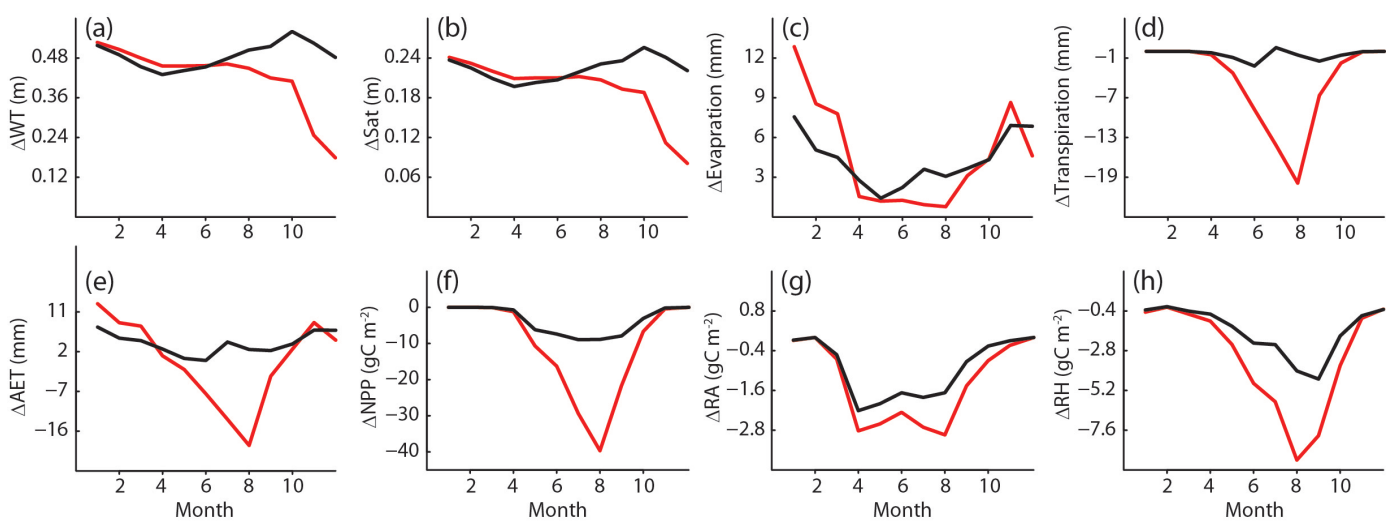

Fig. 7. Comparison of the simulated differences (with vs. without water routing) in monthly values of major hydro-ecological variables between the wet (solid black line) and dry (solid red line) scenarios.

\section{Discussion}

\subsection{Performance and accuracy of R-RHESSys}

Our model evaluation against observed streamflow and derived baseflow from the USGS gauge station indicated that R-RHESSys was able to accurately simulate river flow at watershed scales, largely because all algorithms for water, $\mathrm{C}$ and nutrient dynamics as well as model parameters are maintained as in RHESSys, which itself has been applied and evaluated in a number of studies (e.g., Christensen et al., 2008; Hwang et al., 2012; Tague and Band, 2001). In addition, the simulated ecological variables - such as LAI and forest NPP - all fell within the ranges of corresponding field observations. For example, modeled LAI during the growing season (May to September) averaged $3.1 \mathrm{~m}^{2} \mathrm{~m}^{-2}$ for the entire watershed and ranged from 1.2 to $3.9 \mathrm{~m}^{-2} \mathrm{~m}^{-2}$ across grid cells, agreeing well with observed and modeled values ranging from 2.90 to $4.5 \mathrm{~m}^{2} \mathrm{~m}^{-2}$ in mixed oakhickory forests and northern hardwoods (Scurlock et al., 2001; Tang and Beckage, 2010), dominant forest types in the study watershed. Our modeled annual forest NPP averaged $474 \mathrm{gC} \mathrm{m}^{-2} \mathrm{yr}^{-1}$, falling within the range of 391 to $574 \mathrm{gC} \mathrm{m}^{-2} \mathrm{yr}^{-1}$ of field observations in oak-hickories (e.g., Pan et al., 2006; Tang et al., 2010). Nevertheless, we 
acknowledge that the lack of spatially distributed field measurements - such as observed soil moisture, water table depth, and forest NPP - hinder us from further evaluating the patterns of simulated major ecological and hydrological variables across the watershed. Such limitations in the model's evaluation are encountered commonly in many other distributed-model-based studies (Brooks et al., 2007) and need improvement in the future.

\subsection{Effects of water routing on soil water table depth and saturation deficit}

Lateral water flow and associated water redistribution across the landscape considerably influence hydrologic response in terrestrial ecosystems, including movement and storage of water in the soil (Guntner and Bronstert, 2004; Thompson and Moore, 1996). Some studies (e.g., Kim and Eltahir, 2004) indicated that topography drives lateral transport of water downslope, and water converges into concave areas or valleys through surface or subsurface runoff. As a result, water table depth tends to be significantly shallower in valleys compared to hills. However, this contrasting pattern did not occur in simulations that ignored water routing, in which the simulated water table depth and saturation deficit approximated each other between valleys and hills/ridges of the watershed (Fig. 3b and e). In other words, simulated water table depth and saturation deficit with water routing captured better our preconception of their spatial patterns across the watershed. A similar study in a humid watershed (Hotta et al., 2010) indicated that lateral flow and local infiltration descending from hillslopes often causes lower elevation sites to have a higher water table level and higher elevation sites to have a lower water table level.

A similar model-based comparison study additionally supported our findings. Sonnentag et al. (2008) compared simulated water table depth between simulations with and without considering lateral water flow in a peatland. They found that the magnitude of simulated water table depth without water routing was considerably underestimated because lateral subsurface flow moves water toward the margins of the peat body. The neglect of lateral flow resulted in the simulated water table at or very close to the ground surface, which explains why the simulated water table depth was much greater under simulation ignoring water routing (Table 2). Furthermore, Moore and Thompson (1996) found that the combination of slope curvature, microtopography, and resulting water movement produce significant variability in water table depth across the landscape. This explains why the calculated standard deviation of water table depth among cells doubled (0.40) under simulation considering water routing compared to that (0.19) ignoring water routing (Table 2).

Similar to water table depth, saturation deficit under simulation with water routing showed a distinct pattern in the watershed: higher in the valleys and lower in the hills or ridges of the watershed, which agreed better with findings from
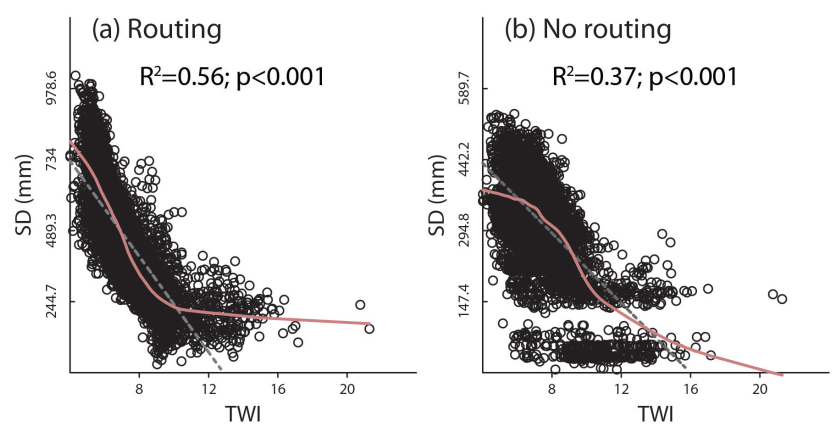

Fig. 8. Comparison of the relationships of simulated saturation deficit (SD) to topographic wetness index (TWI) across the watershed between the two simulations: (a) considering water routing and (b) ignoring water routing.

previous studies. Hopp et al. (2009) found that relatively high saturation in the soil profile occurs in the swale, and drier zone often occurs upslope and on the side ridges of hillslopes when water routing and topography were both considered in the model simulation. Crave and Gascuel-Odoux (1997) indicated that the steeper upslope parts of a watershed will be drained laterally more rapidly than the gentler downslope parts, resulting in drier slopes at the catchment scale. These patterns were captured by simulation with water routing (Fig. 3d) while not always by simulation without water routing (Fig. 3e). In addition, most previous studies indicated that the upslope contributing area, as incorporated into the TOPMODEL (Beven and Kirkby, 1979), is probably the major topographic influence on soil moisture distribution (e.g., Hotta et al., 2010; Thompson and Moore, 1996). This relationship also was captured better by simulation considering water routing as suggested by the strength of the linear relationship of simulated saturation deficit to calculated topographic wetness index (Fig. 8a vs. b) between the two simulations.

\subsection{Effects of water routing on water fluxes from land to the atmosphere}

Slope, aspect and surrounding topography control incident direct solar radiation, and lower-elevation regions in mountainous watersheds have more incoming longwave radiation from the surrounding landscapes plus temperature decreases as elevation increases. The highest ET values often occur in valleys, and the lowest ET in north-facing, high-elevation areas (Bertoldi et al., 2006; Christensen et al., 2008), which explains why the modeled spatial patterns of evaporation and transpiration in the watershed were generally higher in low elevations and valleys and lower in high elevations under the two contrasting simulations (Fig. S3 in the Supplement). Water routing is a major determinant of soil water table and moisture distribution, however, both of which play important roles in modulating water fluxes from land to the atmosphere. 

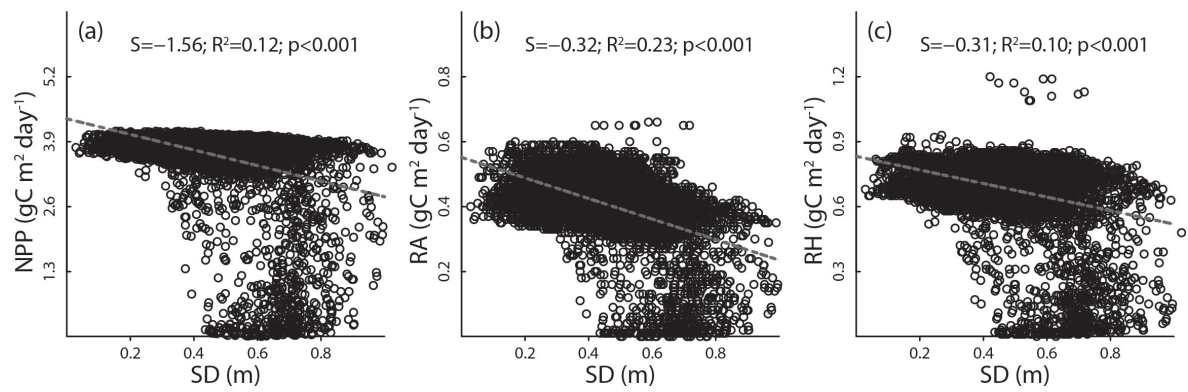

Fig. 9. The relationships of saturation deficit (SD) with (a) net primary productivity (NPP), (b) soil autotrophic respiration (RA), and (c) soil heterotrophic respiration $(\mathrm{RH})$. Data shown here are based on the simulation considering water routing.

For example, Salvucci and Entekhabi (1995) indicated that a deeper water table typically indicates drier areas where evaporation is often suppressed. This explains why there are areas where evaporation under simulation with water routing was lower than those without water routing (Fig. S3c in the Supplement).

In addition, changes in vegetation growth resulting from moisture alteration also can affect water fluxes from land to the atmosphere due to changes in canopy leaf area. Comparing the two simulations, for cells where simulated NPP decreased (less than $-2 \%$, Fig. $5 \mathrm{c}$ ), $60 \%$ experienced an increase in evaporation while $48 \%$ experienced a decrease in transpiration due to decrease in canopy leaf area. This explains why there are areas where simulated evaporation is higher while transpiration is lower under simulation with water routing than that without water routing (Fig. S3c and $\mathrm{f}$ in the Supplement). At the individual cell level, because temperature, soil moisture and vegetation dynamics interact to jointly control evaporation and transpiration, differences in simulated evaporation, and transpiration can be either positive or negative (Fig. S3 in the Supplement). When averaged for the entire watershed, because evaporation showed significant increase by $18 \%$ under simulation with water routing, the resultant AET also showed an increase by $9 \%$ under simulation with water routing compared to that without water routing. In addition, because forest productivity is modeled to be similar in $80 \%$ of areas between the two simulations and because transpiration accounts for two-thirds of total ET plus water is not limited, simulated transpiration and ET were extremely similar in $70 \%$ of areas in the watershed between the two contrasting simulations, although significant differences occurred in some areas (Fig. S3f and i in the Supplement).

\subsection{Effects of water routing on vegetation productivity}

Changes in soil moisture condition affect canopy photosynthesis and forest productivity (Band et al., 1993). Hwang et al. (2012) found that soil moisture content has profound effects on plant growth in forested watersheds. Svoray and Karnieli (2011) indicated that plant productivity is strongly correlated with water redistribution processes. Plants in the lower physiographic units (e.g., footslope, channel) should respond well to improved water and soil conditions and, therefore, should be more productive. In contrast, the interfluve, shoulder, and backslope areas often had lower vegetative greenness values because of poor water availability. In this study, the effects of differences in simulated soil moisture condition on forest productivity were not very noticeable (defined as $-2 \%<$ NPP difference $<2 \%$ ) in $80 \%$ of areas in the study watershed between the two contrasting simulations (Fig. 5). This is largely because incoming solar radiation and temperature are major determinants of forest productivity, and these radiative forcings were identical between the two simulations. Nevertheless, because changes in soil moisture can affect forest productivity and because the saturation deficit was simulated to be greater under the simulation with water routing, simulated forest NPP was significantly lower in steeper slope areas of the watershed when water routing was considered. In these areas where differences in NPP were less than $-2 \%$, average soil saturation deficit $(722 \mathrm{~mm})$ was $45 \%$ higher than that $(498 \mathrm{~mm})$ in areas where differences in NPP were not noticeable (defined as $-2 \%<$ NPP difference $<2 \%$ ) (Fig. 5). In fact, forest NPP was significantly and negatively correlated with saturation deficit in our simulation (Fig. 9a) because the deterioration of soil moisture condition can limit vegetation growth (e.g., Urgeghe et al., 2010).

\subsection{Effects of water routing on soil respiration}

Local topography can generate considerable spatial variability in soil temperature, incoming solar radiation, and soil water content (Running et al., 1987; Kang et al., 2004). Although each of these factors differentially affects soil respiration, soil temperature plays a major role in soil respiration. Kang et al. (2004) found that about $75 \%$ of seasonal variation in soil respiration in such mesic ecosystems can be explained by variation in soil temperature. Because soil temperature is simulated to be the same between the two simulations, this greatly contributed to the similarity (defined as $-2 \%<$ RA difference $<2 \%$ ) of the spatial pattern 

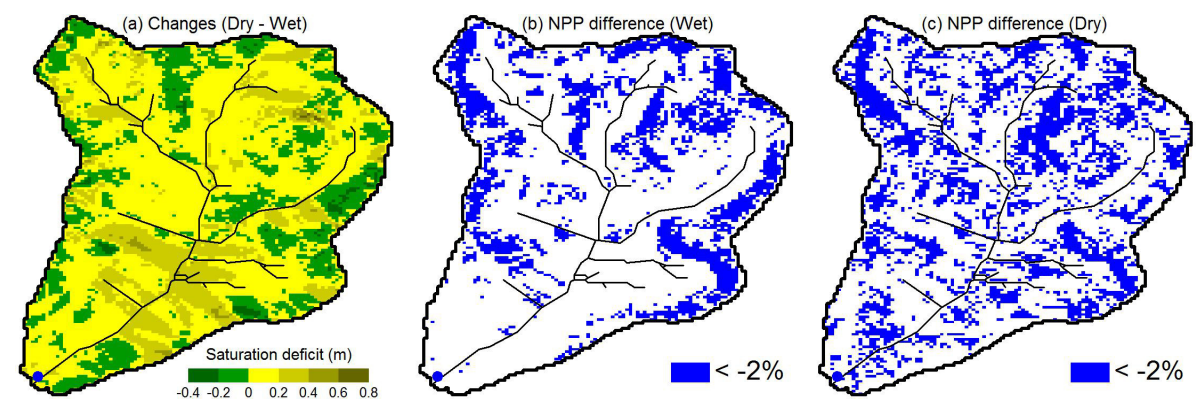

Fig. 10. (a) Deteriortation of soil moisture condition under the dry scenario compared to the wet scenario resulted in NPP decreases occurring in more areas of the watershed (c) under the dry scenario than that (b) under the wet scenario. The white areas show no significant differences.

of simulated soil RA in $79.9 \%$ of areas in the watershed (Fig. 6). Indeed, the calculation of root RA in R-RHESS is mainly treated as a function of soil temperature, following Ryan (1991). Because saturation deficit was higher when water routing was considered, and because soil water deficit limits root production resulting from reduced NPP, the consequent soil RA is smaller under the simulation considering water routing (Fig. 6a-c). In fact, for cells where simulated NPP decreased by less than $-2 \%$ between the two contrasting simulations (Fig. 5c), $99.9 \%$ experienced a decrease in RA, ranging from -1.4 to $-100 \%$ (Fig. 6c). Linear regression also suggested that soil RA is negatively and significantly correlated with saturation deficit (Fig. 9b).

Although soil temperature plays a dominant role in regulating soil RH, changes in soil water content due to lateral flow and connectivity affect litter production and soil microbial activity, which in turn affect soil RH. Riveros-Iregui et al. (2011) indicated that growing-season soil $\mathrm{CO}_{2}$ efflux is known to vary laterally by as much as sevenfold within small subalpine watersheds in the northern Rocky Mountains, and the variability was strongly related to the landscape-imposed redistribution of soil water. Because soil RH in R-RHESSys is treated as a function of soil moisture following Parton et al. (1996), this explains that the simulated soil RH is spatially more variable (higher standard deviation) among cells when water routing is considered (Table 2). In our simulation, for cells where forest NPP decreased by less than $-2 \%$ (Fig. 5c), $97 \%$ experienced a decrease in $\mathrm{RH}$ due to reduction of litter production (Fig. 6f). In a semiarid subalpine watershed, Riveros-Iregui and McGlynn (2009) observed that the highest soil $\mathrm{CO}_{2}$ efflux rates often occur in areas with persistently high soil moisture, whereas lower soil $\mathrm{CO}_{2}$ efflux rates are on forested uplands in subalpine watersheds. Such patterns were captured better under simulation considering water routing (Fig. 6d) than that ignoring water routing (Fig. 6e), partially because soil RH was generally simulated to be low in areas of steeper slopes (Figs. 1 and 6) and because forest NPP and litter production were low in these areas. Compared to soil RA, differences in simulated soil RH between the two contrasting simulations can be either negative or positive due to combined effects of soil temperature, moisture, and litter inputs on RH. Overall, soil RH was negatively correlated to saturation deficit in our simulation, suggesting that neglect of water routing has the potential to cause the model to overestimate soil RH (Fig. 9c).

\subsection{Effects of water routing on $C$ and water dynamics under dry conditions}

Consideration of water routing in model simulations had greater effects on simulated $\mathrm{C}$ and water dynamics under the dry scenario than under the wet scenario, largely because of deterioration of soil moisture condition under the dry scenario (Fig. 10a). For example, when averaged for the entire watershed, soil saturation deficit increased by $14 \%$ under the dry scenario $(0.72 \mathrm{~m})$ compared to the wet scenario $(0.63$ $\mathrm{m})$. The deterioration of soil moisture condition caused the number of cells where the difference in simulated monthly NPP was greater than $2 \%$ to increase by $138 \%$ under the dry scenario (6031 cells) (Fig. 10c) compared to the wet scenario (2531 cells, Fig. 10b). This explained why the absolute magnitudes of the simulated differences in monthly values of $\mathrm{C}$ and water fluxes were greater for those months, in which time series of daily precipitation were set to zero under the dry scenario. Our findings of the greater effects of consideration of water routing on simulated $\mathrm{C}$ and water dynamics under the dry scenario was consistent with Band (1993), who found that spatial variations in available soil water can have significant effects on areal averaged $\mathrm{C}$ and water fluxes rates, particularly under dry conditions.

\section{Conclusions}

Based on R-RHESSys and by keeping all model parameters and their parameterizations identical, this model-based comparison study indicated the following:

1. R-RHESSys is able to correctly simulate streamflow and baseflow for Biscuit Brook regardless of whether water routing is considered in the model simulation or not. When water routing is considered, however, R-RHESSys captures better our preconception of the 
spatial patterns of water table depth and saturation deficit. In contrast, when water routing is neglected, the simulation has a tendency to underestimate water table depth and saturation deficit. Simulated patterns of water table depth and saturation deficit differ from our preconception of the two quantities across the landscape.

2. Differences in simulated water table depth and saturation deficit between simulations with and without water routing affect subsequent water fluxes from land to the atmosphere. At the individual cell level, simulated evaporation, transpiration and ET were spatially more heterogeneous across the landscape when water routing was considered. Although differences in simulated evaporation, plant transpiration, and ET are not significant (absolute difference $<2 \%$ ) in most areas of the watershed, when averaged for the entire watershed, evaporation, transpiration, and ET were simulated to be 4 to $18 \%$ greater under simulation considering water routing than that ignoring water routing.

3. Forest productivity was generally simulated to be smaller and spatially more variable under simulation with water routing due to higher and more variable saturation deficit. Lower forest productivity and root production caused simulated soil RA to be lower when water routing was considered. In contrast, simulated soil RH with water routing can be either greater or smaller than without water routing due to the combined effects of soil moisture, temperature and litter inputs. When averaged for the entire watershed, forest productivity and soil respiration were modeled to be 8 to $11 \%$ less under simulation considering water routing than that ignoring water routing.

Overall, this study indicated that lateral water flow exerts strong control on the spatial pattern and variability of water table depth and saturation deficit (e.g., Band et al., 1993), and such effects are more apparent in dry conditions (e.g., Band, 1993). When averaged for the entire watershed, simulated water fluxes from land to the atmosphere were higher, while forest productivity and soil respiration were less under simulation with water routing than those without water routing. Results of this study further demonstrated that the spatial pattern of soil moisture is fundamental to spatially distributed modeling of eco-hydrological processes (e.g., Band, 1993; Chamran et al., 2002; Hebrard et al., 2006) and suggested that ecosystem and $\mathrm{C}$ cycle models need to explicitly represent water routing because simulation with water routing better captures the patterns of water table depth and saturation deficit across landscapes.
Supplementary material related to this article is available online at http://www.hydrol-earth-syst-sci.net/ 18/1423/2014/hess-18-1423-2014-supplement.pdf.

Acknowledgements. The authors thank the New York City Department of Environmental Protection that provided funding for the research that led to this manuscript. We greatly appreciate Genevieve Ali and other two anonymous reviewers for their constructive comments on earlier version of this manuscript. We sincerely thank Lawrence Band, Elliot Schneiderman, Don Pierson, and Mark Zion for their valuable comments that greatly helped improve this manuscript. This study also benefited from the NSF EPSCoR grant (NSF 0814372) for Nevada.

Edited by: N. Basu

\section{References}

Asbjornsen, H., Goldsmith, G. R., Alvarado-Barrientos, M. S., Rebel, K., Van Osch, F. P., Rietkerk, M., Chen, J., Gotsch, S., Tobon, C., Geissert, D. R., Gomez-Tagle, A., Vache, K., and Dawson, T. E.: Ecohydrological advances and applications in plantwater relations research: a review, J. Plant. Ecol., 4, 3-22, 2011.

Band, L. E.: Effects of land surface representation on forest water and carbon budgets, J. Hydrol., 150, 749-772, 1993.

Band, L. E., Patterson, P., Nemani, R., and Running, S. W.: Forest ecosystem processes at the watershed scale: incorporating hillslope hydrology, Agr. Forest Meteorol., 63, 93-126, 1993.

Bertoldi, G., Rigon, R., and Over, T. H.: Impact of watershed geomorphic characteristics on the energy and water budgets, J. Hydrometeorol., 7, 389-403, 2006.

Beven, K. and Kirkby, M.: A physically-based variable contributing area model of basin hydrology, Hydrol. Sci. Bull., 24, 43-69, 1979.

Brooks, E. S., Boll, J., and McDanil, P. A.: Distributed and integrated response of a geographic information system-based hydrologic model in the eastern Palouse region, Idaho, Hydrol. Process., 21, 110-122, 2007.

Caylor, K. K., Manfreda, S., and Rodriguez-Iturbe, I.: On the coupled geomorphological and ecohydrological organization of river basins, Adv. Water Resour., 28, 69-86, 2005.

Chamran, F., Gessler, P. E., and Chadwick, O. A.: Spatially explicit treatment of soil-water dynamics along a semiarid catena, Soil Sci. Soc. Am. J., 66, 1571-1583, 2002.

Chen, J. M., Chen, X., Ju, W., and Geng, X.: Distributed hydrological model for mapping evapotranspiration using remote sensing inputs, J. Hydrol., 305, 15-39, 2005.

Christensen, L., Tague, C. L., and Baron, J. S.: Spatial patterns of simulated transpiration response to climate variability in a snow dominated mountain ecosystem, Hydrol. Process., 22, 35763588, 2008.

Crave, A. and Gascuel-Odoux, C.: The influence of topography on time and space distribution of soil surface water content, Hydrol. Process., 11, 203-210, 1997. 
Doten, C. O., Bowling, L. C., Lanini, J. S., Maurer, E. P., and Lettenmaier, D. P.: A spatially distributed model for the dynamic prediction of sediment erosion and transport in mountainous forested watersheds, Water Resour. Res., 42, W04417, doi:10.1029/2004WR003829, 2006.

Gérard-Marchant, P., Hively, W. D., and Steenhuis, T. S.: Distributed hydrological modelling of total dissolved phosphorus transport in an agricultural landscape, part I: distributed runoff generation, Hydrol. Earth Syst. Sci., 10, 245-261, doi:10.5194/hess-10-245-2006, 2006.

Goovaerts, P.: Ordinary cokriging revisited, Math. Geol., 30, 21-42, 1998.

Guntner, A. and Bronstert, A.: Representation of landscape variability and lateral redistribution processes for large-scale hydrological modelling in semi-arid areas, J. Hydrol., 297, 136-161, 2004.

Hebrard, O., Voltz, M., Andrieux, P., and Moussa, R.: Spatiotemporal distribution of soil surface moisture in a heterogeneously farmed Mediterranean catchment, J. Hydrol., 329, 110121, 2006.

Hopp, L., Harman, C., Desilets, S. L. E., Graham, C. B., McDonnell, J. J., and Troch, P. A.: Hillslope hydrology under glass: confronting fundamental questions of soil-water-biota coevolution at Biosphere 2, Hydrol. Earth Syst. Sci., 13, 21052118, doi:10.5194/hess-13-2105-2009, 2009.

Hotta, N., Tanaka, N., Sawano, S., Kuraji, K., Shiraki, K., and Suzuki, M.: Changes in groundwater level dynamics after lowimpact forest harvesting in steep, small watersheds, J. Hydrol., $385,120-131,2010$.

Hwang, T., Band, L. E., Vose, J. M., and Tague, C.:. Ecosystem processes at the watershed scale: Hydrologic vegetation gradient as an indicator for lateral hydrologic connectivity of headwater catchments, Water Resour. Res., 48, W06514, doi:10.1029/2011WR011301, 2012.

Ivanov, V. Y., Bras, R. L., and Vivoni, E. R.: Vegetation-hydrology dynamics in complex terrain of semiarid areas: 2. Energywater controls of vegetation spatiotemporal dynamics and topographic niches of favorability, Water Resour. Res., 44, W03430, doi:10.1029/2006WR005595, 2008.

Ju, W., Chen, J. M., Black, A. B., Barr, A. G., McCaughey, H., and Roulet, N. T.: Hydrological effects on carbon cycles of Canada's forests and wetlands, Tellus B, 58, 16-30, 2006.

Kang, S., Lee, D., and Kimball, J. S.: The effects of spatial aggregation of complex topography on hydro-ecological process simulations within a rugged forest landscape: development and application of a satellite-based topoclimatic model, Can. J. For. Res., 34, 519-530, 2004.

Kim, Y. and Eltahir, E. A. B.: Role of topography in facilitating coexistence of trees and grasses within savannas, Water Resour. Res., 40, W07505, doi:10.1029/2003WR002578, 2004.

Lane, S. N., Reaney, S. M., and Heathwaite, A. L.: Representation of landscape hydrological connectivity using a topographically driven surface flow index, Water Resour. Res., 45, W08423, doi:10.1029/2008WR007336, 2009.

Moore, R. D. and Thompson, J. C.: Are water table variations in a shallow forest soil consistent with the TOPMODEL concept?, Water Resour. Res., 32, 663-669, 1996.
Nash, J. E. and Sutcliffe, J. V.: River flow forecasting through conceptual models part I - A discussion of principles, J. Hydrol., 10, 282-290, 1970.

Pan, Y., Birdsey, R., Hom, J., McCullough, K., and Clark, K.: Improved estimates of net primary productivity from MODIS satellite data at regional and local scales, Ecol. Appl., 16, 125-132, 2006.

Parton, W. J., Mosier, A. R., Ojima, D. S., Valentine, D. W., Schimel, D. S., Weier, K., and Kulmala, A. E.: Generalized model for $\mathrm{N}_{2}$ and $\mathrm{N}_{2} \mathrm{O}$ production from nitrification and denitrification, Global Biogeochem. Cy., 10, 401-412, 1996.

Pockman, W. T. and Small, E. E.: The Influence of Spatial Patterns of Soil Moisture on the Grass and Shrub Responses to a Summer Rainstorm in a Chihuahuan Desert Ecotone, Ecosystems, 13, 511-525, 2010.

Price, M. F., Gratzer, G., Duguma, L. A., Kohler, T., Maselli, D., and Romeo, R. (Eds.): Mountain Forests in a Changing World - Realizing Values, addressing challenges, FAO/MPS and SDC, Rome, 2011.

Quinn, P., Beven, K., Chevallier, P., and Planchon, O.: The prediction of hillslope flow paths for distributed hydrological modeling using digital terrain models, Hydrol. Process., 5, 59-79, 1991.

Ridolfi, L., D'Odorico, P., Porporato, A., and Rodriguez-Iturbe, I.: Stochastic soil moisture dynamics along a hillslope, J. Hydrol., 272, 264-275, 2003.

Riveros-Iregui, D. A. and McGlynn, B. L.: Landscape structure control on soil $\mathrm{CO}_{2}$ efflux variability in complex terrain: Scaling from point observations to watershed scale fluxes, J. Geophys. Res.-Biogeo., 114, G02010, doi:10.1029/2008JG000885, 2009.

Riveros-Iregui, D. A., McGlynn, B. L., Marshall, L. A., Welsch, D. L., Emanuel, R. E., and Epstein, H. E.: A watershed-scale assessment of a process soil $\mathrm{CO}_{2}$ production and efflux model, Water Resour. Res., 47, W00J04, doi:10.1029/2010WR009941, 2011.

Running, S. W., Nemani, R. R., and Hungerford, R. D.: Extrapolation of Synoptic Meteorological Data in Mountainous Terrain and Its Use for Simulating Forest Evapotranspiration and Photosynthesis, Can. J. Forest Res., 17, 472-483, 1987.

Ryan, M. G.: Effects of climate change on plant respiration, Ecol. Appl., 1, 157-167, 1991.

Salvucci, G. D. and Entekhabi, D.: Hillslope and Climatic Controls on Hydrologic Fluxes, Water Resour. Res., 31, 1725-1739, 1995.

Scurlock, J. M. O., Asner, G. P., and Gower, S. T.: Global Leaf Area Index from Field Measurements, 1932-2000, Data source: Oak Ridge National Laboratory Distributed Active Archive Center, Oak Ridge, Tennessee, USA, http://www.daac.ornl.gov, 2001.

Singh, R., Jhorar, R. K., van Dam, J. C., and Feddes, R. A.: Distributed ecohydrological modelling to evaluate irrigation system performance in Sirsa district, India II: Impact of viable water management scenarios, J. Hydrol., 329, 714-723, 2006.

Smith, M. B., Koren, V., Reed, S., Zhang, Z., Zhang, Y., Moreda, F., Cui, Z., Naoki, M., Anderson, E. A., and Cosgrove, B. A.: The distributed model intercomparison project - Phase 2: Motivation and design of the Oklahoma experiments, J. Hydrol., 418-419, 3-16, 2012.

Smith, M. W., Bracken, L. J., and Cox, N. J.: Toward a dynamic representation of hydrological connectivity at the hillslope scale in semiarid areas, Water Resour. Res., 46, W12540, doi:10.1029/2009WR008496, 2010. 
Sonnentag, O., Chen, J. M., Roulet, N. T., Ju, W., and Govind, A.: Spatially explicit simulation of peatland hydrology and carbon dioxide exchange: Influence of mesoscale topography, J. Geophys. Res.-Biogeo., 113, G02005, doi:10.1029/2007JG000605, 2008 .

Sponseller, R. A. and Fisher, S. G.: The influence of drainage networks on patterns of soil respiration in a desert catchment, Ecology, 89, 1089-1100, 2008.

Svoray, T. and Karnieli, A.: Rainfall, topography and primary production relationships in a semiarid ecosystem, Ecohydrology, 4, 56-66, 2011.

Tague, C. L. and Band, L. E.: Evaluating explicit and implicit routing for watershed hydro-ecological models of forest hydrology at the small catchment scale, Hydrol. Process., 15, 1415-1439, 2001.

Tague, C. L. and Band, L. E.: RHESSys: regional hydro-ecologic simulation system - an objected-oriented approach to spatially distributed modeling of carbon, water and nutrient cycling, Earth Interact., 8, 1-42, 2004.

Tang, G. and Arnone III, J.: Trends in surface air temperature and temperature extremes in the Great Basin during the $20^{\text {th }}$ century from ground-based observations, J. Geophys. Res.-Atmos., 118, 3579-3589, 2013.

Tang, G. and Beckage, B.: Projecting the distribution of forests in New England in response to climate change, Divers. Distrib., 16, 144-158, 2010.

Tang, G., Beckage, B., Smith, B., and Miller, P. A.: Estimating potential forest NPP, biomass and their climatic sensitivity in New England using a regional dynamic ecosystem model, Ecosphere, $1,1-20,2010$.
Thompson, J. C. and Moore, R. D.: Relations between topography and water table depth in a shallow forest soil, Hydrol. Process., 10, 1513-1525, 1996.

Thompson, S., Katul, G., Konings, A., and Ridolfi, L.: Unsteady overland flow on flat surfaces induced by spatial permeability contrasts, Adv. Water Resour., 34, 1049-1058, 2011.

Urgeghe, A. M., Breshears, D. D., Martens, S. N., and Beeson, P. C.: Redistribution of Runoff Among Vegetation Patch Types: On Ecohydrological Optimality of Herbaceous Capture of Run-On, Rangeland Ecol. Manage., 63, 497-504, 2010.

Vogelmann, J. E., Sohl, T., Campbell, P. V., and Shaw, D. M.: Regional land cover characterization using landsat thematic mapper data and ancillary data sources, Environ. Monit. Assess., 51, 415-428, 1998a.

Vogelmann, J. E., Sohl, T., and Howard, S. M.: Regional characterization of land cover using multiple sources of data, Photogramm. Eng. Remote. Sens., 64, 45-47, 1998b.

Wang, J. H., Yang, H., Li, L., Gourley, J. J., Sadiq, I. K., Yilmaz, K. K., Adler, R. F., Policelli, F. S., Habib, S., Irwn, D., Limaye, A. S., Korme, T., and Okello, L.: The coupled routing and excess storage (CREST) distributed hydrological model, Hydrolog. Sci. J., 56, 84-98, 2011.

Wang, L., Koike, T., Yang, K., Jackson, T. J., Bindlish, R., and Yang, D.: Development of a distributed biosphere hydrological model and its evaluation with the Southern Great Plains Experiments (SGP97 and SGP99), J. Geophys. Res.-Atmos., 114, D08107, doi:10.1029/2008JD010800, 2009.

Wigmosta, M., Vail, L., and Lettenmaier, D.: Distributed hydrology-vegetation model for complex terrain. Water Resour. Res., 30, 1665-1679, 1994. 